\title{
AKTIVITAS KEBERAGAMAAN PARA PEKERJA MIGRAN INDONESIA DI HONG KONG
}

\author{
M. Syarif ${ }^{1}$ \\ gilangcempaka78@gmail.com \\ Ali Muchasan ${ }^{2}$ \\ ali@iaih.ac.id
}

\begin{abstract}
Abstrak
Artikel ini memperbincangkan tentang aktivitas keberagamaan para pekerja migran Indonesia di Hong Kong. Fokus utamanya diletakkan pada karakteristik keberagamaan mereka selama berada di negeri orang serta apa saja aktivitas mereka guna memenuhi tuntuhan layanan pendidikan agama demi mengisi kebutuhan spiritual mereka selama berada di Hong kong dalam rangka bekerja. Artikel yang berbentuk studi eksploratif ini menggunakan buku, artikel di jurnal, berita di media, dan wawancara sebagai basis referensi untuk menyajikan data.
\end{abstract}

Kata Kunci : Pekerja Migran Indonesia, Hong Kong, Pendidikan Agama, Karakteristik Beragama, Aktivitas Agama

1 Dosen Tetap Universitas Islam Majapahit (UNIM) Mojokerto

2 Dosen Tetap Institut Agama Islam Hasanuddin (IAIH) Pare Kediri 


\begin{abstract}
This article discusses the religious activities of Indonesian migrant workers in Hong Kong. The focus is placed on their religious characteristics while in other countries and what their activities are to fulfill the demands of religious education services in order to fulfill their spiritual needs while in Hong Kong for work. This article in the form of an exploratory study uses books, articles in journals, news in the media, and interviews as a reference base to present data.
\end{abstract}

Keywords: Indonesian Migrant Workers, Hong Kong, Religious Education, Religious Characteristics, Religious Activities

\title{
A. PENDAHULUAN
}

Menjalankan kewajiban agama bagi seorang muslim Indonesia yang berada di negeri orang, dimana umat muslim menjadi minoritas, tentu bukan sebuah hal mudah. Jika berangkat dan berdiam di negeri orang harus dilakukan demi mencari nafkah dan mempertahankan hidup misalnya, maka disana terbentang tantangan untuk tetap menjadi diri sendiri dengan seluruh atribut budaya dan agama, keindonesiaan dan keislaman sekaligus, pada sebuah negeri yang kebudayaan dan komunitas beragamanya mungkin saja berbeda.

Pada konteks ini, seorang muslim selain dituntut untuk bekerja mencari nafkah, dia juga harus memenuhi kebutuhan spiritualnya untuk untuk beribadah dan mendapatkan penyegaran ruhani melalui Pendidikan agama. Disini seorang pekerja di luar negeri akan menghadapi dilemma.

Sebagai contoh, saat berada di negeri di mana muslim adalah minoritas, seseorang akan sulit menemukan masjid. Kondisi ini berbeda dengan berada di negeri sendiri dimana kita bisa menemukan masjid di setiap komplek perumahan. Ini juga sama halnya dengan menemukan musholla yang akan jarang ditemukan di bangunan perkantoran atau mall. Tetapi beribadah adalah kebutuhan sekaligus kewajiban dimana seorang muslim di manca negara negara tetap harus berusaha mencari atau paling tidak mengusahakan secara mandiri tempat yang layak untuk melaksanakan beribadah. ${ }^{3}$

\footnotetext{
${ }^{3}$ Dalam kunjungannya ke Hong Kong dan Macau, K.H Marzuki Wahid, yang dikenal sebagai aktivis HAM dan Rektor Institut Studi Islam Fahmina (ISIF) Cirebon pada Maret 2019 menegaskan sebagai berikut, "Mayoritas penduduk Hong Kong memeluk agama Budha, Konghucu, dan Tao. Sementara agama Islam, Hindu, Kristen, Yahudi termasuk agama minoritas di Hong Kong. Oleh karena itu, dibanding dengan Indonesia, suasana keagamaan di Hong Kong sangat berbeda. Kesan sekuler lebih kuat ketimbang religius. Ini tidak lain karena Hong Kong memosisikan diri sebagai kota perdagangan metropolis. Dengan jumlah penduduk Islam yang minoritas, saya merasakan sendiri betapa sulit mencari masjid atau musholla di sana. Dalam hal ini, kita tidak bisa membandingkan Hong Kong dengan Indonesia yang hampir setiap desa atau
} 


\section{Di sisi lain, masalah konsumsi pun menjadi dilema tersendiri. Sebagai} kebutuhan primer manusia, makanan adalah hal penting yang harus dipenuhi. Masalahnya, saat berada di negeri non muslim masalah lumrah menjadi harus diperhatikan terkait dengan hukum halal haramnya. Di Indonesia, seseorang tak akan kesulitan untuk mendapatkan makanan halal untuk dia konsumsi, karena makanan halal bisa ditemukan di mana saja. Namun di negeri minoritas muslim kondisinya berbeda, dia harus lebih hati-hati dalam memilih makanan agar tidak terjerembab mengkonsumsi makanan yang tak selaras dengan ajaran agama.

Dari sisi budaya dan pergaulan, seseorang juga dituntut untuk tetap menjaga dirinya sembari terus berpegang pada nilai-nilai budaya asal serta prinsip-prinsip religius yang dianut. Konteks inilah yang paling sulit untuk dipertahankan oleh seorang pekerja migran Indonesia di luar negeri. ${ }^{4}$ Bagaimanapun, lingkungan pergaulan sangat berpengaruh terhadap perubahan perilaku seseorang jika tak diiringi oleh usaha untuk intensif mengisi aspek spiritualnya. ${ }^{5}$

Banyak pemberitaan media massa membawa kabar mengenai kasus bunuh dirinya seorang PMI di luar negeri. ${ }^{6}$ Alih-alih terkait masalah relasi kerja antara pekerja

kelurahan memiliki masjid atau musholla”. Kesulitan serupa juga terjadi saat seseorang mau mengambil wudlu mengingat di wilayah seperti Honkong media paling umum yang dipakai untuk membersihkan anggota tubuh setelah buang air adalah tissue dan bukan air, sedangkan menggunakan air setelah buang air di toilet dianggap sebagai tindakan kurang beradab. Lihat, https://buruhmigran.or.id/en/2019/03/22/beragama-di-negeri-minoritas-muslim/ di akses pada 17 Novemberr 2021 pukul 19.00

4 Pada konteks ini sebenarnya terdapat kontradiksi dalam hal pergaulan sosial dan budaya masyarakat di negara maju dimana seorang pekerja migran berdiam. Sementara aspek hubungan-hubungan antar lawan jenis disana sedemikian bebas dan bisa dipandang sebagai berhadapan dengan nilai ajaran Islam, tetapi budaya kehidupan bermasyarakatnya dapat dipandang sebagai lebih Islami daripada Indonesia, misalnya budaya kebersihan, ketertiban, budaya antri, dan profesionalitas dalam hal pelayanan publik.

5 Sebagai penduduk pendatang yang mencari nafkah di negeri orang, seorang pekerja migran harus bisa memposisikan diri dan menyesuaikan diri secara kontekstual pada tempat dia berada dan bekerja mencari nafkah. Budaya, tradisi, dan aturan hukum setempat harus dihargai. Dalam konteks ini, berlaku kaidah fiqhiyyah: al-'aadatu muhakkamatun (bahwa tradisi yang berlaku dapat dijadikan ketentuan hukum). Sementara itu di sisi lain, mereka juga harus tetap waspada untuk mempertahankan nilai-nilai luhur dari budaya asli dan agamanya sendiri. Kita bisa membayangkan dilema psikis sosiologis yang dialami oleh seorang pekrja migran ketika nilai-nilai religius yang dipeluknya berhadapan dengan budaya sekitar dimana dia dituntut untuk menyesuaikan diri. Jika tak tertangani secara serus oleh pihak-pihak yang berwenang dan peduli, masalah nini bias menjerumuskan sebagian besar pekrja migran untuk larut dalam budaya sekitarnya yang bias menyeretnya kedalam pergauilan yang bertentangan dengan nilai-nilai luhur agama, perseingkuhan misalnya. Dalam konteks inilah bimbingan keagamaan yang intensif dan sekaligus memiliki sudut pandang kekinian benar-benar mereka butuhkan.

6 Situs merdeka.com, news.detik.com dan diiringi oleh beberapa situs portal berita lain pada tahun 2019 menyampaikan berita seorang TKW asal Kalipare Malang Jawa Timur melakukan perbuatan bunuh diri. Sebelumnya sempat muncul isu bahwa aksi bunuh diri tersebut dilatarbelakangi masalah utang piutang, tetapi ternyata tidak terbukti. Korban memang betul-betul bunuh diri karena motif permasalahan pribadi. "Dari informasi yang kami terima, kasus ini ada hubungannya dengan masalah asmara. Itu informasi yang 
dan majikan, malah diduga kuat bahwa kasus bunuh diri tersebut berlatarbelakang masalah hubungan pribadi sang PMI yang berbau asmara dengan seorang lelaki. Kasus lain yang kerap menjadi topik pemberitaan adalah perselingkuhan dimana seorang PMI menyia-nyiakan keluarganya di Indonesia karena terlibat hubungan asmara dengan orang lain di luar negeri. ${ }^{7}$

Kasus-kasus itu menunjukkan bahwa dalam beberapa hal, ada kekosongan spiritual atau kurangnya siraman ruhani yang dialami oleh pekerja migran tersebut yang membuatnya mengambil kepoutusan pendek kendatripun perbuatannya merupakan dosa besar dalam ajaran agama. Dan apapun alasan bunuh diri tersebut, itu menunjukkan bahwa penyegaran dan sekaligus penguatan spiritualitas yang berbasis ajaran agama tetaplah sangat penting untuk senantiasa diusahakan oleh para pekerja migran tersebut.

Disini peran penting penting pendidikan agama menjadi tak dapat diabaikan. Rentang waktu yang lama dalam mencari nafkah di negeri orang dengan budaya yang sangat jauh berbeda, mampu untuk menggoyahkan sendi-sendi keyakinan seseorang terhadap nilai-nilai moral dan religiusitas yang selama ini dipegangnya. Dan jika kondisi ini tetap dibiarkan kering, ia akan menjadi benalu yang kian hari kian menggerogoti ketahanan mental dan kestabilan jiwa sang pekerja migran yang akan mendiringnya untuk melakukan tindakan-tindakan destruktif yang justru merugikan bagi dirinya sendiri.

Usaha-usaha untuk terus mendapatkan pendidikan agama sesungguhnya juga secara kontinyu dilaksanakan oleh para PMI di Hong Kong. Sebagaimana akan dibicarakan nanti, usaha pendidikan tersebut mengambil bentuk bermacam-macam justru demi memenuhi kebutuhan spiritual seperti yang disebutkan diatas.

Itu sebabnya mengapa banyak sekali Da'i, Ustadz, Kyai dan para penceramah Indonesia yang kerapkali dating ke Hong Kong untuk memberikan ceramah agama.

\footnotetext{
kami terima, di luar itu tidak ada yang lain," ungkap kata Muhammad Iqbal, Kepala Pos Pelayanan, Penempatan dan Perlindungan Tenaga Kerja Indonesia (P4TKI) Malang Jawa Timur. Berdasarkan informasi yang diterima, korban memiliki hubungan baik dengan majikannya. Bahkan yang bersangkutan telah memperpanjang kontrak kerja untuk kali kedua. Lihat, https://news.detik.com/berita-jawa-timur/d4387663/tkw-asal-malang-meninggal-di-Hong Kong-dikabarkan-bunuhdiri?.ga=2.189246955.1540539177.1641705687-978666873.1641705687 di akses pada hari Sabtu, 11 Desember 2021 pukul 14.00

7 Situs grid.id pada Januari 2018 silam mengangkat berita tentang seorang pria yang istrinya berkeja sebagai PMI di Hong Kong. Pria itu pun mengungkapkan kepiluannya melalui media sosial Facebook, yang kemudian dicapture dan diunggah akun Instagram @lurahkita, pada Jumat 26 Januari 2018. Pada tulisannya di media sosial itu, ia menceritakan anaknya sedang sakit dan terus memanggil nama ibunya. Pria yang kini berstatus duda itupun merasakan penderitaan anaknya yang sedang sakit. Namun istrinya sudah tidak peduli padanya dan anaknya karena lebih memilih pria lain.
} 
Mereka dating bukan atas dasr undangan dari pemrintah atau masyarakat asli Hong Kong sendiri, melainkan lebih sering diundang oleh para pekerja migran Indonesia yang bediam disana.

Tulisan ini menyoroti masalah tersebut diatas. Ia berbincang mengenai pendidikan agama dan keagamaan yang dijalani komunitas pekerja migran Indonesia di Hong Kong, sementara aspek kehidupan keagamaan yang lebih luas hanya akan disinggung sekilas. Sebagaimana akan dijelaskan, perhatian terutama akan lebih diberikan pada pendidikan keagamaan non-formal, mengingat komunitas muslim Indonesia ini rata-rata adalah pekerja yang sanat sulit untuk menempuh pendidikan secara formal. Alasan utamanya ialah pekerja migran Indonesia merupakan segmen terbesar dari komunitas muslim Indonesia di hong Kong. mereka yang hampir seluruhnya wanita bekerja sebagai pembantu rumah tangga di berbagai tempat di hong Kong. Karena mereka tidak diperkenankan membawa keluarga atau menikah, maka mereka sendirilah yang menjadi konsumen utama dari layanan pendidikan keagamaan, yang umumnya dilakukan dalam bentuk aktivitas pendidikan non-formal.

Dalam hal ini, patut digarisbawahi bahwa kebutuhan pendidikan formal selalu seiring dengan kepentingan untuk memperoleh ijazah sebagai basis pengakuan keahlian dan intelektualitas seseorang. ${ }^{8}$ Sedangkan para pekerja migran ini tak memiliki

\footnotetext{
8 Sulit dalam hal ini bukannya tak mungkin. Beberapa pekerja migran masih memiliki kesempatan untuk melanjutkan pendidikannya hingga mencapai gelar sarjana. Di tengah-tengah kesibukan mereka bekerja sebagai asisten rumah tangga di negeri orang, diantara mereka ada yang melanjutkan studinya pada berbagai perguruan tinggi dengan sistem ekstensi mapun perkuliahan jarak jauh. Dilaporkan di migranpos.com pada September 2019 sebanyak 150 pekerja migran Indonesia di wisuda di ruang pertemuan kapal pesiar Star Pisces sedang yang bersandar di pelabuhan Tsim Sha Tsui setelah menempuh Pendidikan selama empat tahun di Saint Mary University Hong Kong dimana perkuliahannya dilaksanakan pada setiap hari Sabtu dan Minggu. 150 PMI yang di wisuda itu lulus sebagai sarja S1 dalam bidang Magemen Bisnis, Perdagangan, dan Bahasa Inggris. Mereka di wisuda bersama dengan wisudawan lain yang berasal Filipina dan Nigeria. Acara wisuda itu sendiri bahkan sempat dihadiri oleh Atase Pendidikan Kedutaan Besar Ri di Beijing. Lihat, http://migranpos.com/2019/09/27/kuliah-sambil-bekerja-150-pmiwisuda-di-kapal-pesiar/ di akses pada 29 September 2021 Sementara itu pada April 2021 tatkala masa pandemi terlewati, sebanyak 2525 Pekerja Migran Indonesia (PMI) di Hong Kong yang merupakan mahasiswa Universitas Terbuka (UT) tercatat berhasil menyelesaikan pendidikannya dan diwisuda pada Upacara Penyerahan Ijazah UT Hong Kong 2021. Sebanyak 25 lulusan tersebut terdiri atas lulusan Program Studi Sastra Inggris Bidang Minat Penerjemahan, Manajemen, Akuntasi, Ilmu Komunikasi, dan Administrasi Bisnis. Acara wisuda itu sendiri dilaksanakan secara luring dan daring untuk mencegah penyebaran pandemi Covid-19. Sebanyak 23 lulusan mengikuti upacara secara langsung di Hong Kong dan dua lulusan lagi mengikuti acara tersebut secara secara daring. Lihat pada, https://www.beritasatu.com/nasional/765455/25-pekerja-migran-indonesia-di-hong-kong-diwisuda di akses pada 29 September 2021.
} 
kepentingan yang bersifat akademis tersebut. Kecuali misalnya mereka boleh membawa anak-anak mereka yang bisa disekolahkan di Lembaga Pendidikan Islam formal disana. ${ }^{9}$

Secara khusus, tulisan ini difokuskan untuk menjawab pertanyaan:

1. Bagaimana kondisi para pekerja migran Indonesia di Hong Kong ?.

2. Bagaimana karakteristik kehidupan beragama para pekerja migran Indonesia di Hong Kong ?.

3. Apa saja aktifitas yang mereka adakan guna memenuhi tuntutan kebutuhan pendidikan agama mereka sekaligus menjadi penyedia jasa layanan pendidikan agama bagi mereka di Hong Kong?

Sebagai sebuah studi eksploratif berbasis literatur, tulisan ini menggunakan media-media yang tersedia berupa buku-buku, jurnal, situs web dan media sosial sebagai bahan baku referensinya. Tulisan ini diharapkan bermanfaat untuk memberikan pengetahuan kita mengenai kondisi para pekerja migran di Hong Kong terkait dengan interaksi sosial budayanya, khususnya mengenai kehidupan kegamaan selama berada di negeri orang.

Manfaat lain adalah mengangkat kepedulian kita agar kedepannya kita dapat memberikan sumbangsih pemikiran terkait bagaimana menyediakan layanan jasa poendidikan yang lebih efeektif guna memenuhi tuntutan kebutuhan mereka terhadap pendidikan agama.

\section{B. METODE PENELITIAN}

Pendekatan penelitian yang digunakan untuk mengetahui studi aktifitas kebergaman para pekerja migran Indonesia di Hongkong adalah penelitian eksploratif secara kualitatif.

\footnotetext{
9 Ungkapan diatas tidak berarti menafikan keberadaan Lembaga Pendidikan Islam formal di Hong Kong. Tercatat, sebagaimana dipaparkan oleh Rudi Harisyah Alam, Di Hong Kong terdapat 7 sekolah Islam yang dikelola oleh komunitas muslim, yang ironisnya, tidak pernah didirikan baik oleh organisasi para pekerja migran muslim Indonesia maupun atas kepedulian pemerintah Republik Indonesia, melainkan oleh masyarakat etnis China dan Pakistan. Lima dari 7 sekolah itu dikelola oleh Chinese Muslim Cultural and FraternalAssociation, sedangkan dua sekolah lainya dikelola masing-masing oleh United MuslimsAssociation of Hong Kong (UmAh) dan Incorporated Trustees of the Islamic Community Fund of Hong Kong. Sekolah-sekolah itu menyedikan pelajaran agama Islam yang umumnya tidak disediakan oleh sekolah-sekolah umumcdi Hong Kong, Lihat Rudi Harisyah Alam, Pendidikan Keagaman pada Komunitas Muslim Indonesia di Hong Kong, dalam Jurnal Edukasi, Jurnal Penelitian Pendidikan agama dan Keagamaan, Vol 14 No, 3 (Desember 2016). Hal. 336
} 
Peneltian eksploratif merupakan penelitian yang bertujuan untuk menggali secara luas tentang sebab-sebab atau hal-hal yang mempengaruhi terjadinya sesuatu dan dipakai manakala kita belum mengetahui. Metode penelitian eksploratif adalah penelitian yang bertujuan untuk memetakan suatu objek secara relatif mendalam. ${ }^{10}$

\section{HASIL DAN PEMBAHASAN}

\section{Kondisi Pekerja Migran Indonesia di Hong Kong}

Sebelum beranjak pada pembahasan mengenai aktivitas keberagamaan pekerja migran Indonesia di Hong Kong, ada baiknya memperbincangkan mengenai sejarah para pekerja migran Indonesia bekerja di luar negeri. Hal ini demi mempejelas bagi kita bahwa karakteristik masyarakat Indonesia meskipun telah berdiam lama di luar negeri mereka masih tetap memegang kuat tradisi kegamaannya.

Bekerja di luar negeri bagi sebagian masyarakat Indonesia bukanlah sebuah fenomena baru. Pada masa sebelum kemerdekaan, migrasi tenaga kerja Indonesia (TKI) ke luar negeri dilakukan oleh pemerintah Hindia Belanda melalui penempatan buruh kontrak ke negara Suriname, Amerika Selatan, yang juga merupakan wilayah koloni Belanda. ${ }^{11}$

Setelah Indonesia merdeka, hingga akhir 1960-an, penempatan Tenaga Kerja Indonesia ke luar negeri masih belum melibatkan pemerintah kendatipun sudah dibentuk Kementerian Perburuhan, penempatan tenaga kerja Indonesiua dilakukan secara orang perorang, kekerabatan, dan bersifat tradisonal. Negara tujuan utamanya adalah Malaysia dan Arab Saudi yang berdasarkan hubungan agama (haji) serta lintas batas antarnegara.

Penempatan TKI yang didasarkan pada kebijakan pemerintah Indonesia baru terjadi pada 1970 yang dilaksanakan oleh Departemen Tenaga Kerja, Transmigrasi, dan

\footnotetext{
${ }^{10}$ Lexy J, Moleong, Metode Penelitian Kualitatif, (Bandung: PT. Remaja Rosdakarya, 2008), Hal. 6

11 Sejak 1890 pemerintah Belanda mulai mengirim sejumlah besar kuli kontrak asal Jawa bahkan Madura, Sunda, dan Batak untuk dipekerjakan di perkebunan di Suriname. Tujuannya untuk mengganti tugas para budak asal Afrika yang telah dibebaskan pada 1 Juli 1863 sebagai wujud pelaksanaan politik penghapusan perbudakan sehingga para budak tersebut beralih profesi serta bebas memilih lapangan kerja yang dikehendaki. Dampak pembebasan para budak itu membuat perkebunan di Suriname terlantar dan mengakibatkan perekonomian Suriname yang bergantung dari hasil perkebunan turun drastis. Adapun dasar pemerintah Belanda memilih TKI asal Jawa adalah rendahnya tingkat perekonomian penduduk pribumi (Jawa) akibat meletusnya Gunung Merapi dan padatnya penduduk di Pulau Jawa. Gelombang pertama pengiriman TKI oleh Belanda diberangkatkan dari Batavia (Jakarta) pada 21 Mei 1890 dengan Kapal SS Koningin Emma. Pelayaran jarak jauh ini singgah di negeri Belanda dan tiba di Suriname pada 9 Agustus 1890. Jumlah TKI gelombang pertama sebanyak 94 orang terdiri 61 pria dewasa, 31 wanita, dan 2 anak-anak. Kegiatan pengiriman TKI ke Suriname yang sudah berjalan sejak 1890 sampai 1939 mencapai 32.986 orang, dengan menggunakan 77 kapal laut. Lihat, Sejarah Badan Perlindungan Pekerja Migran Indonesia (BP2MI) di https://bp2mi.go.id/profil-sejarah diakses pada 1 Oktober 2021 pukul 09.00
} 
Koperasi dengan dikeluarkannya Peraturan Pemerintah No 4/1970 melalui Program Antarkerja Antardaerah (AKAD) dan Antarkerja Antarnegara (AKAN), dan sejak itu pula penempatan TKI ke luar negeri melibatkan pihak swasta (perusahaan pengerah jasa TKI atau pelaksana penempatan TKI swasta. ${ }^{12}$ Dan sejak saat itu pemberangkatan Tenaga Kerja Indonesia ke luar negeri selalu mengalami peningkatan dari tahun ketahun dengan jumlah negara tujuan yang lebih variatif bukan hanya Malaysia dan Arab Saudi. ${ }^{13}$ Istilah Tenaga Kerja Indonesia (TKI) itu sendiri dewasa ini diganti menjadi Pekerja Migran Indonesia (PMI), sebutan dan singkatan inilah yang kebelakang akan selalu digunakan.

Terkait dengan arus keberangkatan bekerja ke luar negeri yang terus mengalami peningkatan ini, dapat dimaklumi mengingat besarnya jumlah penduduk yang membutuhkan lapangan pekerjaan serta tingginya minat mereka untuk merantau mencari lahan penghidupan di negeri orang. Indonesia sendiri dikenal memiliki penduduk terbesar ke empat di dunia setelah Cina, India dan Amerika. ${ }^{14}$ Sejak lama, wilayah kepulauan ini dihuni oleh berbagai suku yang memiliki bahasa berbeda-beda. Beberapa suku di negara ini memang dikenal sebagai suku yang suka mengembara atau merantau. ${ }^{15}$ Entah itu mengembara demi keperluan membangun ikatan-ikatan kekeluargaan yang lebih besar dan semarak, ataupun demi kepentingan mendapatkan penghidupan yang lebih memadai bagi hidup mereka di negeri rantau. Disamping memiliki tradisi merantau yang kuat, mereka juga dikenal sebagai bangsa yang religius dan sangat kokoh dalam penghayatan beragama.

Dapat dikatakan bahwa merantau untuk mencari lapangan pekerjaan sudah ada pada tradisi bangsa sejak dahulu dan bukan hanya dimulai pada momen tatkala pemerintah Belanda mengirim TKI ke Suriname pada 1890. Dan seiring berjalannya

12 Tercatat ada sekitar 322 Perusahaan Penempatan Pekerja Migran Indonesia menurut data yang disimpan oleh BP2MI. Banyaknya jumlah perusahaan yang bergerak dibidang pemberangkatan tenaga kerja Indonesia keluar negeri ini menunjukkan kepada kita bagaimana antusisme masyarakat Indonesia untuk bekerja di manca negara.

13 Saat ini, Malaysia dan Arab Saudi bukan lagi satu-satunya negera tujuan seperti dulu di era 60 an.

14 Dikutip dari https://id.wikipedia.org/wiki/Daftar_negara_menurut_jumlah_penduduk pada senin 6 Oktober 2021 pukul 14.00

15 Menurut Mochtar Naim fenomena migrasi telah mewarnai berbagai suku bangsa di Indonesia. Migrasi merupakan suatu perpindahan penduduk dari suatu daerah ke daerah lain. Migrasi lebih dikenal oleh masyarakat Indonesia dengan sebutan merantau dan merupakan tradisi yang sudah ada sejak dulu kala. Fenomena merantau adalah hal yang lazim ditemukan pada masyarakat di banyak tempat di Indonesia. catatan sejarah menunjukkan bahwa berbagai etnik di Indonesia sudah melakukan aktivitas merantau ke derah lain diluar daerah asalnya, seperti orang Bawean, orang Batak, orang Banjar, orang Minangkabau, orang Bugis, orang Manado, orang Ambon, orang Bengkulu, dan orang Mandar dari Sulawesi Selatan. Lihat, Mochtar Naim, Merantau, Pola Migrasi suku Miangkabau, (Jakarta, Rajawali Press, 2013), hal.55 
waktu, tradisi ini mengalami diversifikasi bukan hanya merantau dari daerah ke daerah di dalam negeri sendiri, namun menjangkau belahan bumi lain di manca negara. Lebih-lebih di masa kini, dimana jumlah penduduk Indonesia yang telah memasuki usia produktif dan membutuhkan penghasilan semakin bertambah besar dan proses untuk berangkat ke luar negeri semakin dipermudah oleh hadirnya alat tansportasi yang canggih serta perijinan yang cepat. ${ }^{16}$

Disana terdapat banyak factor yang menyebabkan semakin bertambahnya jumlah pekerja migran ini, di antaranya adalah: mereka yang menjadi pekerja migran Indonesia tersebut tidak memiliki lahan pertanian atau lahan usaha lainnya, mereka mengalami bencana alam yang mengakibatkan rusaknya lahan pertanian sebagai mata pencarian keluarga, mereka memiliki lahan tetapi tidak subur sehingga kurang produktif untuk dijadikan lahan pertanian, serta lahan yang mereka miliki terjual atau berpindah tangan ke orang lain. ${ }^{17}$ Faktor-faktor lain yang bisa disebut adalah kejenuhan menghadapi situasi hidup, adanya pengetahuan tentang peradaban baru, keinginan menyesuaikan diri dengan perubahan, dan keinginan untuk meningkatkan produktifitas atau tingkat perekonomian. ${ }^{18}$

Wilayah yang mereka tuju untuk bekerja bukan hanya satu negara. Disana terdapat banyak pilihan negara yang bisa mereka datangi. Biasanya, negara yang kita kenal sebagai tujuan penduduk Indonesia untuk bekerja adalah Saudi Arabia, Singapura, Malaysia, Taiwan, dan Hong Kong. Tetapi diantara berbagai pilihan tersebut, Hong Kong adalah fenomena tujuan migran yang menarik untuk dicermati dan dikaji.

\footnotetext{
${ }^{16}$ Konteks menjadi TKW atau pekerja migran di negeri orang hampir selalu memiliki motivasi-motivasi ekonomi untuk mencari lahan penghidupan yang lebih layak. Ini yang biasa kita baca dan dengar kendatipun latar belakang awal mengapa mereka memilih untuk berangkat ke luar negeri memiliki sebabsebab yang berbeda-beda. Banyak diantara PMI ini berangkat karena kehidupan rumah tangga yang berantakan dan demi menghidupi anak-anak di kampung halaman, mereka memilih untuk untuk mejadi Asisten Rumah Tangga di negeri orang dimana pekerjaan ini memang tak membutuhkan keahlian khusus. Lebih-lebih telah diketahui bahwa upah bekerja di luar negeri jauh lebih tinggi daripada di dalam negeri, Lihat, Haning Romdiati, "Migrasi Tenaga Kerja Indonesia dari Tulungagung: Kecenderungan dan Arah Migrasi serta Remitansi", Jurnal Kependudukan Indonesia Vol. VI, No. 2 (Desember, 2012), 30-31

${ }^{17}$ Lihat, Wahidah Zein Br Siregar, Kisah Perempuan Pekerja Migran Indonesia Di Hong Kong: Perjuangan Untuk Keluarga Dan Pendidikan Anak, dalam Al Hukama, The Indonesian Journal of Islamic Family Law, Volume 10, Nomor 02, Desember 2020, hal. 243

18 Lihat, Agus Baihaqi, Agus Baihaqi et al, "Komunikasi Keluarga Buruh Migran Indonesia: Masalah dan Penyelesaian”, dalm Jurnal JIKE Vol. 1, No. 2 (Juni, 2018), hal. 168
} 
Hong Kong adalah salah satu kawasan yang memerlukan tenaga kerja dari luar lumayan besar. ${ }^{19}$ Sebagai bagian dari negara China setelah lepas dari koloni Ingris di tahun 1997, Hong Kong memantabkan dirinya sebagai wilayah perekonomian yang kokoh dan membutuhkan banyak tenaga kerja. ${ }^{20}$ Bukan hanya dari satu negara, tenaga kerja yang datang ke Hong Kong meliputi penduduk dari berbagai negara, tak terkecuali pekerja migran yang datang dari Indonesia. Tercatat lebih dari 150.000 pekerja migran Indonesia mencari nafkah di Hong Kong. ${ }^{21}$ Jumlah yang besar ini menunjukkan betapa tingginya minat untuk mencari nafkah di wilayah bagian negara tirai bambu tersebut. Hong kong bahkan juga disebut sebagai surganya para pekerja migram. ${ }^{22}$

19 Menurut Sekretaris Tenaga Kerja dan Kesejahteraan Hong Kong Law Chi-kwong dalam temu media pada senin 21 Januari 2019, populasi penduduk Hong Kong semakin didominasi lanjut usia. Karena itu kota Hong Kong akan banyak membutuhkan tenaga kerja migran termasuk dari Indonesia. "Populasi penduduk tua akan membutuhkan tenaga kerja rumah tangga yang cukup besar," tandasnya. Pemerintah Hong Kong memproyeksikan pada 2036, jumlah penduduk lansia Hong Kong akan mencapai 2,37 juta jiwa atau sekitar 31 persen dari populasi. Dengan demografi kependudukan yang didominasi lansia, Hong Kong akan membutuhkan sekitar 600 ribu pekerja rumah tangga untuk 30 tahun ke depan. Saat ini, tercatat 360 ribu pekerja migran di Hong Kong bekerja sebagai asisten rumah tangga dan caregiver. Dari jumlah tersebut 165 ribu diantaranya atau sekitar 43 persen berasal dari Indonesia. Dikutip dari https://menara62.com/kebutuhan-tenaga-kerja-migran-kota-hong-kong-meningkat/ pada hari Jumat 8 Oktober 2021 pukul 15.00

${ }^{20}$ Hong Kong merupakan salah satu Daerah Administrasi Khusus Republik Rakyat Cina. Melalui Konvensi Peking tahun 1860, wilayah Hong Kong disewakan dan menjadi koloni Britanian Raya selama 99 tahun sejak 1 Juli 1898 dan berakhir 30 Juni 1997. Pada 1 Juli 1997, Hong Kong secara resmi diserahkan kepada Republik Rakyat Cina. Otonomi diberikan melalui kebijakan "Satu Negara Dua Sistem" ciptaan Deng Xiaoping, otonomi tersebut meliputi sistem hukum, mata uang, bea cukai, imigrasi, dan peraturan jalan yang tetap berjalan di jalur kiri. Urusan yang ditangani oleh Beijing adalah pertahanan nasional dan hubungan diplomatik. Otonomi ini akan berlaku di Hong Kong (minimal) selama 50 tahun dihitung sejak tahun 1997. Secara geografiis, Hong Kong memiliki luas wilayah $1.103 \mathrm{~km}^{2}$ yang terdiri dari Pulau Hong Kong, Kowloon dan Wilayah Baru, termasuk lebih 260 kepulauan. Sebagai wilayah sub-tropis, Hong Kong memiliki beberapa musim, seperti musim panas (Mei-September), musim gugur (September-Desember), musim dingin (Desember-Februari), dan musim semi (Maret-Mei).Penduduk di Hong Kong menggunakan bahasa Inggris dan Tionghoa (Kantonis dan Mandarin resmi secara de facto) sebagai bahasa resmi. Kanton adalah dialek bahasa Tionghoa 95\% penduduk Hong Kong. Namun, bahasa Inggris tetap digunakan di bidang pariwisata dan perdagangan. dikutip dari : https://buruhmigran.or.id/2011/05/15/informasi-negaratujuan-tki-Hong Kong/ pada Selasa 7 Oktober 2021 pukul 14.00

21 Jumlah para pekerja asal Indonesia di Hong Kong terus bertambah. Hingga kini total ada sekitar 165.000 pekerja yang menggeluti berbagai jenis pekerjaan di sana. Apa yang menarik dari bekerja di Hong Kong bukan hanya gajinya yang mencapai 8 juta rupiah per bulan, melainkan juga sikap pemerintah Hong Kong dalam memperlakukan para Pekerja Migran disana yang diperlakukan sama dengan warga negara asli Hong Kong. "Semua pekerja di Hong Kong memiliki hak yang sama dengan warga negara Hong Kong sendiri. Mereka juga memiliki waktu libur di setiap minggu," ungkap Chief of Secretaries for Labor and Welfare Bureau, Law Chi-kwong, dalam diskusi Hong Kong Economic \& Trade Office (HKETO) di Hotel Fairmont Jakarta, pada Senin 21 Januari 2019. Dikutip dari : https://ekonomi.kompas.com/read/2019/01/22/063800826/pekerja-indonesia-di-hong-kong-terusbertambah-berapa-gajinya dikutip pada Selasa 7 Oktober 2021 pukul 16.00

${ }^{22}$ Dalam hal ketenagakerjaan asing, Hong Kong bisa menjadi contoh negara penempatan yang beradab, manusiawi, dan menghormati harkat dan martabat tenaga kerja asing, sehingga dapat menjadi standar dalam menentukan negara penempatan bagi pekerja migran indonesia (PMI). Bisa dikatakan, PMI di Hong Kong lebih bisa merasakan kenyamanan bekerja di negara tersebut dibanding di negara-negara lain, seperti Arab 
Fenomena Pekerja Migran Indonesia (PMI) di Hong Kong memiliki keistimewaan tersendiri dibanding pekerja migran di negara lainnya. Disamping sikap ramah warga Hong Kong terhadap pekerja Migran, gaji yang lumayan besar, yang juga menjadi Hong Kong ekspresi keagamaan tidak dibatasi sehingga imigran muslim yang tinggal disana dapat menikmati kebebasan beribadah yang sesuai dengan naluri religiusitas mereka. Tingkat kekerasan yang terjadi terhadap para pekerja migran di Hong Kong menduduki ranking paling rendah diantara 10 negara tujuan pekerja migran. ${ }^{23}$ Patut ditegaskan bahwa pemerintah Hong Kong memberikan perlakukan yang relatif setara antara penduduk asli dengan penduduk migran yang bekerja disana. Sikap yang ramah terhadap pekerja migran ini tak pelak menjadi daya tarik utama bagi para pekerja migran untuk memilih Hong Kong sebagai negara tujuan paling favorit. ${ }^{24}$ Data dari BNP2MI menunjukkan grafik tertinggi Hong Kong sebagai negara penempatan yang paling banyak dituju sebagaimana ditunjukkan pada gambar dibawah.

\footnotetext{
Saudi dan negara-negara Timur Tengah, Brunei Darussalam, Singapura, Malaysia, Korea Selatan, negaranegara di Eropa, dan Amerika. Dengan biaya hidup yang lebih rendah dibanding negara-negara penerima PMI lainnya, tenaga kerja Indonesia di Hong Kong lebih leluasa dalam mengatur keuangan, termasuk mengikuti gaya hidup modern di wilayah tersebut. Selain itu, tidak ada batasan yang menghambat mereka mengekspresikan kebebasan, baik dalam berkumpul maupun mengomentari berbagai hal, termasuk membicarakan isu-isu hangat di Indonesia. Dikutip dari : https://indonesiaglobalworker.com/2019/07/20/hong-kong-referensi-impian-para-pekerja-migranindonesia/ pada Kamis 7 Oktober pukul 19.00

${ }^{23}$ Arab Saudi adalah negara yang tingkat kekerasan tertinggi, dimana dari 41.412 kasus pengaduan di pusat crisis center BNP2TKI, sebanyak 14.807 kasus pengaduan PMI yang bekerja di Arab Saudi dan PMI yang mendapatkan tindak kekerasan adalah PMI yang bekerja sebagai Penata Laksana Rumah Tangga ( PLRT) atau sering disebut dengan domestic workers2, selain Arab Saaudi ada beberapa negara tertinggi yang menerima TKW dan kekerasan terhadap TKW juga cukup tinggi antara lain adalah Malaysia sebanyak 14.807 kasus, Yordania sebanyak 9.357 kasus, Syriah sebanyak 8.675 kasus, Uni Emirat Arab sebanyak 8.234 kasus, Taiwan sebanyak 8.035 kasus, Kuwait sebanyak sebanyak 7.845, Singapura sebanyak Kasus 7.280, Oman sebanyak 6.908kasus, dan Hogkong sebanyak 6.590 kasus. Dari data-data di atas, Arab Saudi adalah negara ke 3 tujuan terbesar oleh PMIyang mana pekerja nya lebih didominasi oleh domestic workers, dan Arab Saudi adalah negara yang tingkat kekerasan terhadap PMI yang paling tinggi dan Arab Saudi berada diurutan pertama tingkat kekerasan terhadap PMI yang bekerja sebagai domestic workers.Berbanding terbalik dengan Hong Kong, Hong Kong adalah negara tujuan para PMI terbesar ke 4. Meskipun di Hong Kong para PMI juga mendapatkan kekerasan seperti dinegara-negara Malaysia dan Arab Saudi, namun kekerasan yang dihadapi para PMI yang ada di Hong Kong jauh lebih sedikit dibandingkan kekerasan yang didapat oleh para PMIyang ada di Arab dan negara-negara tujuan terbesar lainnya. Dapat dilihat dari kasus yang ada di Arab Saudi dan Hong Kong, dimana di Arab Saudi memiliki sebanyak 41.412 kasus sedangkan Hong Kong hanya memiliki 6.590 kasus yang dihadapi oleh para PMI. Sumber : BP2MI 24 Kendati begitu, bukannya tak ada pekerja migran Indonesia yang mengalami nasib kurang menyenangkan selama bekerja disana. Sebagaimana ditulis I Nengah Darthayasa, banyak juga cerita duka yang menimpa perempuan pekerja migran Indonesia, seperti mengalami berbagai bentuk kekerasan yang sampai mengganggu tidak hanya kesehatan fisik tetapi juga kesehatan jiwa. Lihat, I Nengah Darthayasa et al, "Pengalaman Tenaga Kerja Indonesia (TKI) yang Mengalami Abuse", Jurnal Ilmu Keperawatan Vol. 4 No. 2 (November, 2016), hal. 149-158
} 


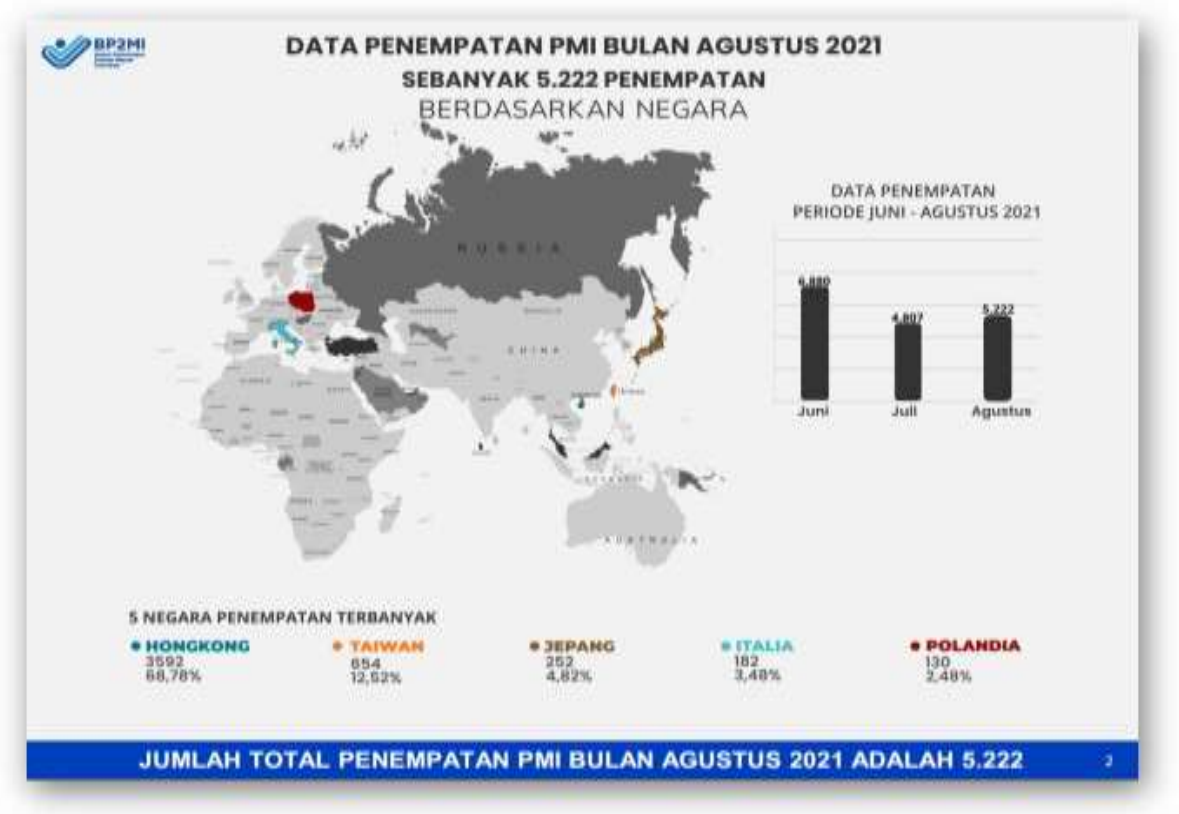

Warga Hong Kong pun menurut penuturan sebagian besar PMI umumnya sangat menghargai mereka. Sedikit sekali bahkan bisa dikatakan hampir tidak pernah terjadi kasus kekerasan yang menimpa PMI lebih dari itu, sejumlah PMI melaporkan bahwa disamping kewajiban untuk melaksanakan tugas-tugas harian, ada diantara mereka yang diberikan kesempatan untuk melanjutkan pendidikannya.

Realitas bahwa Hong Kong adalah lokasi penempatan favorit bagi sebagian besar pekerja migran Indonesia ini juga yang menarik penulis untuk mengeksplorasi karakteristik keberagamaan mereka selama berada disana sekaligus bagimana cara mereka memenuhi tuntutan akan pendidikan agama.

\section{Karakteristik Keberagamaan Pekerja Migran Indonesia di Hong Kong}

Beragama adalah fenomena universal yang tampil sepanjang zaman dalam sejarah umat manusia. Mengutip Fransisco J Moreno, sejarah agama berumur setua sejarah manusia. Tidak ada suatu masyarakat yang hidup tanpa agama. ${ }^{25}$ Thesis ini menunjukkan kepada kita bahwa beragama telah menjadi cetak biru dalam diri manusia yang akan tetap ada sepanjang rentang sejarah. Bahkan, Fredrich Max Muller, bapak studi agama modern kelahiran Jerman, bahkan menegaskan bahwa, "The real history of men is the history of religions", realitas sejarah umat manusia adalah sejarah agama. Kita dapat

25 Lihat, Francicsco J Moreno, Agama Dan akal Pikiran, Naluri Rasa Takut dan Keadaan Jiwa Manusia, (Jakarta, Rajawali Press, 2000). Hal. 45 
menafsirkan ungkapan ini sebagai sebuah penegasan bahwa agama akan selalu ada dalam kehidupan manusia kedatipun manusia kontemporer telah beranjak mendaki peradaban yang lebih tinggi dengan seluruh atribut ilmu pengetahuan/sains modern mereka dan jauh melampaui peradaban nenek moyangnya yang mewariskan agama pada mereka. ${ }^{26}$

Konteks kepentingan beragama ini dilukiskan oleh Joachim Wach dalam penegasan bahwa agama merupakan penerang bagi jiwa manusia, kehidupan, dan sejarah. Ia adalah kebutuhan metafisis manusia yang berfungsi melengkapi kebutuhan fisiknya. Atau bisa jadi justru aspek metafisis ini lebih utama mengingat manusia tak akan pernah mencapai keseimbangan dalam hidupnya sebelum dia lebih dulu menata kondisi kejiwaannya. Dan penataan kondisi kejiwaan ini tak bisa dipenuhi oleh aspek-aspek material mengingat aspek ini bisa segera habis. Manusia membutuhkan yang eternal untuk jiwanya yang juga bersifat eternal. Dan yang eternal itu adalah penciptanya, yaitu Tuhan. Seperti yang ditegaskan oleh amsal Bakhtiar, agama adalah suatu sistem kepercayaan kepada Tuhan agar manusia selalu bisa mengadakan interaksi dengan-Nya. Tuhan dan hubungan manusia dengan-Nya merupakan aspek metafisika, sedangkan manusia sebagai makhluk dan bagian dari benda alam termasuk dalam kategori fisika. ${ }^{27}$ Manusia membutuhkan hubungan dengan yang metafisis ini demi keutuhan esensi dalamnya yang bukan metafisis. ${ }^{28}$

Secara tradisional, ketika orang ingin mendapat jawaban atas pertanyaan mendasar dalam kehidupan, "di manakah kita? Mengapa kita hadir disini ? apa tujuan kita disini “ dan akan kemana kita setelah ini?” mereka akan berpaling kepada teks-teks wahyu

\footnotetext{
${ }^{26}$ Huston Smith menegaskan bahwa semenjak bangkitnya ilmu pengetahuan modern semakin banyak manusia yang berpaling padanya untuk mendapatkan jawaban. Ini dapat dimengerti, karena eksperimeneksperimen yang dilakukan secara terkontrol memungkinkan ilmu pengetahuan untuk membuktikan berbagai tesisnya, dan dengan tesis-tesis tersebut ilmu pengetahuan telah mengubah wajah dunia. Tetapi di penghujung abad ini, ada tanda yang menunjukkan yang membuat kita sadar bahwa tindakan untuk sepenuhnya percaya pada ilmu pengetahuan modern adalah keliru. Sebab ilmu pengetahuan (dan anak turunnya : teknologi) memiliki tempatnya sendiri. Yang salah adalah ketika kita mengharapkan ilmu pengetahuan dapat menjawab pertanyaan-pertanyaan penting dan mendasar dalam hidup, sebab metodenya memang tak sesuai untuk itu. Lihat, Huston smith, Agama-Agama Manusia, (Jakarta, Serambi, 2015), Hal. 11

${ }^{27}$ Amsal Bakhtiar, Filsafat Agama, Wisata Pemikiran dan Kepercayaan Manusia, (Jakarta, Raja Grafindo Persada, 2007). Hal. 2

${ }^{28}$ Jika mau kita bandingkan, semisal sebuah produk berbentuk robot didistribusikan ke sebuah dunia. Kendatipun telah dibawa pergi oleh seorang pembeli ia akan tetap membutuhkan campurtangan pembuatnya (sang pencipta) jika ada masalah dalam penggunaannya, minimal dalam konteks ini adanya petunjuk teknis (buku manual) penggunaan yang bisa kita ibratkan sebagai wahyu dan terkodifikasi dalam agama. Disana dibutuhkan garansi dari produsen robot tersebut sebagai jalur hubungan antara sang robot dengan sang pembuat jika ada kerusakan justru agar sang robot tetap bisa berfungsi efektif mengikuti fitrahnya.
} 
yang ada dalam agama atau kepada berbagai mitos nenek moyang yang diwariskan kepada mereka bila mereka adalah kaum yang terbiasa dengan tradisi lisan. Tetapi pada intinya adalah sama, yaitu mereka akan berpaling kepada agama. ${ }^{29}$ Menurut Milton Yinger, manusia memerlukan nilai-nilai mutlak sebagai pegangan dan jawaban terhadap persoalan hidup dan mati. Sedangkan nilai-nilai mutlak tersebut sulit dicari pada budaya temporal perkembangan peradaban manusia, bahkan pada teknologi sekalipun, kendati yang terakhir ini acapkali diandalkan untuk menjawab berbagai persoalan kehidupan.

Mengikuti ungkapan Mircea Eliade, Manusia adalah „Homo Religius ${ }^{e e}$, makhluk yang akan selalu mencari agama tempat dia mendapatkan ketenangan batin serta serta sandaran saat berbagai permasalah yang bisa dijawab secara material tampil kedepan membentur hidupnya. Pada titik ini kita menyadari bahwa fenomena manusia beragama begitu bersifat perennial justru karena agama memberikan jawaban pada masalah yang paling mendasar, yaitu tentang keberadaannya di dunia ini dan akan kemana dia nanti. Fenomena ini tak akan pernah berhenti pada satu fase pun dalam perjalanan hidup kemanusiaan pada masa kapanpun dan di wilayah manapun. Itu sebabnya kita tetap akan menemui fenomena masyarakat beragama meskipun di nagara paling modern sekalipun semisal Amerika. apalagi Indonesia yang telah lama dicatat dalam sejarah sebagai kepulauan yang dihuni oleh masyarakat religius.

Dalam konteks masyarakat beragama di Indonesia, telah lama diketahui bahwa penduduk di kepulauan nusantara ini adalah komunitas masyarakat religius yang telah memiliki keyakinan keagamaan tak terhitung jumlahnya. Bahkan jauh sebelum datangnya agama-agama besar dunia ke kepulauan ini -seperti Hindu, Buddha, Islam, Kristen, Katolik- masyarakat nusantara telah memiliki keyakinan-keyakinan religius yang disinergikan dengan ajaran agama-agama besar tersebut saat mereka hadir.

Sejak zaman purbakala hingga Indonesia merdeka, sesungguhnya penduduk nusantara telah memiliki keyakianan-keyakinan dan agama-agama lokal. Kehidupan reiligius bangsa Indonesia begitu kental dan mendalam, hal ini dapat dilihat dari sejarah panjang kemerdekaan bangsa Indonesia yang tidak lepas dari kekuatan agama yang selalu menemaninya. ${ }^{30}$

\footnotetext{
29 Smith. ..... Agama, Hal, 11

30 Zulkarnain, Warga Negara Religius sebagai Identitas Kewarganegaraan di Indonesia, Prosiding Konferensi Nasional Kewarganegaraan III, Universitas Ahmad Dahlan, Yogyakarta, 11 November 2017. hal. 37
} 
Jiwa keberagamaan/religiusitas masyarakat kepulauan nusantara ini telah membaku menjadi tradisi ribuan tahun yang diwariskan dari satu generasi ke generasi selanjutnya sejak zaman purba hingga ke era modern sekarang ini. Dalam kata yang sederhana, penduduk nusantara adalah masyarakat yang telah mengenal konsep beragama sejak dahulu kala yang difungsikan untuk menata hidup dan perilakunya seharihari sekaligus menjadi pedoman bagi segenap interaksi sosial.

Maka tak heran apabila tradisi beragama ini dibawa kemanapun mereka pergi. Termasuk dalam konteks ini para Pekerja Migran Indonesia yang tinggal selama beberapa waktu di luar negeri. Kegiatan-kegiatan keagamaan yang mereka adakan secara rutin disela waktu libur mereka. ${ }^{31}$ Darisana terlihat bagaimana mereka tetap menjunjung tinggi tradisi nenek moyang mereka untuk senantiasa menjadikan agama sebagai panutan hidup kendatipun lingkungan yang mereka tempati telah dipunuhi oleh aspek-aspek modernitas yang kadang membuat orang lupa pada nilai-nilai luhur ajaran Tuhan. Pertanyaanpertanyaan yang mereka ajukan sebagaimana tergambar dalam buku Karya Marzuki Wahid diatas menunjukkan peningkatan keterlibatan pekerja migran Indonesia di luar negeri dalam kegiatan keagamaan salah satunya bertujuan untuk tetap berpegang pada prinsip keberagamaan mereka kendatipun mereka berada di negeri orang.

Demikian pula dengan pekerja migran Indonesia yang berada di Hong Kong. Sifat religiusitas khas penduduk nusantara ini tetap melekat kendatipun mereka berada di negara yang kebudayaannya berbeda dan justru jauh lebih maju daripada Indonesia. Sebagaimana akan kita lihat dibelakang nanti mengenai aktivitas keberagamaan mereka serta usaha-usaha Pendidikan yang mereka lakukan, betapa terlihat bahwa sikap religious mereka serta kerinduan atas praktik dan suasana keagamaan sangat mencolok di kalangan pekerja Migran Indonesia di Hong Kong. Kebebasan ekspresi dan berkumpul serta jaminan hari libur yang dimiliki memberi kesempatan kepada PMI untuk menikmati hari libur dengan menikmati aktivitas keagamaan. Dimana aktivitas tersebut tidak terpusat di masjid-masjid, namun juga di ruang-ruang publik, seperti taman kota, beberapa bahu jalan, dan pusat-pusat pertemuan. Tidak jarang pula aktivitas keagamaan dilakukan di tempat-tempat yang disewa PMI atau yang disediakan gratis oleh organisasi yang ada di Hong Kong sebagaimana akan kita bahas lebih jauh dibelakang.

\footnotetext{
31 Lihat, Alam, ....... Pendidikan, hal. 342
} 
Kerinduan dan pencarian keagamaan tersebut diekspresikan pula dalam beragam bentuk dan keterbatasan. Hal tersebut dilakukan untuk menerobos batas keterbatasan guru dan tempat bertanya. Beragam fenomena muncul dalam upaya pencarian tersebut, baik pada tataran individu maupun kelompok. Sebagai contoh, secara kolektif terdapat beberapa kelompok yang menggelar aktivitas berkala "Ngaji Youtube". Istilah ini digunakan untuk menunjuk aktivitas keagamaan di mana peserta secara bersama-sama menonton

kajian

keagamaan di Youtube dan membahas isinya. Kajian tersebut dilakukan tanpa guru pendamping. Kajian-kajian yang dipilih pun kebanyakan didasarkan atas popularitas penceramah di kanal-kanal Youtube. Ini adalah ciri khas baru dalam upaya mengaji agama dengan memanfaatkan media teknologi informasi modern. ${ }^{32}$

Darisana kita dapat memlihat betapa gairah keagamaan yang mencengangkan tersebut menjadi karakteristik keberagamaan mereka. Gairah ini tak pernah lekang oleh tempat dan budaya yang berbeda yaitu bahwa mereka adalah komunitas religious yang suka hidup bergotongroyong dalam hal aktivitas keagamaan, persis sebagaimana muslim di Indonesia kerap melaksanakan acara-acara keagamaan yang diadakan dan dinikmati Bersama. Hanya bedanya, apabila di Indonesia komunitas pengajian maupun halaqah baca Al Quran banyak ditempatkan di Masjid atau Musholla, maka para PMI tersebut menggunakan ruang-ruang publik yang diijinkan untuk mereka pakai sebagai tempat untuik melakukan aktivitas Pendidikan keagamaan.

Itu bisa ditunjuk sebagai karakteristik religiusitas yang unik bila dibanding dengan gaya beragama muslim lain di belahan dunia yang lain. Mereka mengibarkan gaya hidup religius yang jauh lebih mencengangkan daripada tradisi beragama saudara-saudara mereka sendiri yang berada di Indonesia. Mereka ada di negeri orang, tetapi kemauan mereka untuk berkumpul dan menghadiri majelis ilmu dan pendidikan keagamaan mengalahkan hasrat untuk bersenang-senang tatkala menggunakan waktu liburan yang mereka miliki hanya satu hari dalam seminggu setelah enam hari mereka dipayahkan oleh sekian banyak perintah dan tugas dari majikan.

32 Lihat, Marzuki wahid \& Imam Nakha'i, Fikih Pekerja Migran, Respon atas Masalah-Masalah Pekerja Migran Indonesia di Negara Tujuan Kerja, (Yogyakarta, INFEST, 2021), hal. vii . Aktifitas "Ngaji Youtube" tampaknya berkembang seiring dengan pembatasan sosial yang merebak pada saat pandemic Covid-19 sebagimana pula mereka mulai akrab dengan aplikasi zoom untuk melakukan diskusi-diskusi jarak jauh saat badan tak diperkanankan untruk didekatkan. 


\section{Aktivitas Pendidikan Agama Pekerja Migran Indonesia di Hong Kong}

Tidak berlebihan jika dikatakan Hong Kong adalah surganya TKI. Surga dalam pengertian, mereka mendapatkan penghasilan yang layak sebagaimana gaji TKI di negara-negara lain, tetapi di sisi lain biaya hidup yang lebih murah memungkinkan mereka memiliki simpanan atau mengikuti gaya hidup warga setempat. Selain itu, tidak ada aturan-aturan yang membatasi TKI untuk berkumpul bersama komunitasnya, melakukan aktivitas sebagaimana warga setempat, termasuk bersama-sama melakukan aktivitas keagamaan. ${ }^{33}$

Perlakuan simpatik pemerintah Hong Kong terhadap buruh migran Indonesia tersebut telah menjadi lahan subur bagi tumbuh kembangnya kajian-kajian keislaman dan berbagai pengajian serta acara keagamaan yang diadakan oleh mereka secara swadaya. Sudah banyak para Da'i, Ustadz/ustadzah, serta agamawan yang berkunjung ke Hong Kong atas undangan para migran tersebut. ${ }^{34}$ Bukan berita asing lagi jika da'i-da'i kondang seperti Gus Miftah, K.H Anwar Zahid, Ustadz Abdus Shomad, Habib Syech, dan lainlain kerap memberikan ceramah dihadapan para Pekerja Migran Indonesia di Hong Kong.

Secara fenomenologis, kita melihat bagaimana keinginan untuk menimba ilmu agama dan melaksanakan kewajiban keagamaan tampak sangat kental pada pekerja migran Indonesia tersebut. Kajian-kajian rutin mereka dengan mengundang para penceramah dari dalam negeri menunjukkan bahwa semangat keberagamaan mereka justru semakin meningkat tatkala mereka berada di negeri orang. ${ }^{35}$

Dalam hal ini harus digaribawahi, sebagaimana ditegaskan oleh Rudi Harisyah Alam dalam laporan penelitiannya, bahwa dari segi kuantitas, mayoritas muslim di Hong

\footnotetext{
${ }^{33}$ Lihat, https://setkab.go.id/hong-kong-surganya-tki/ yang merupakan situs resmi Sekretariat Kebinet Republik Indonesia. Di akses pada Rabu 6 Oktober 2021 pukul 19.00

34 Sebagian besar para PMI yang bekerja di Hong Kong menganggap bahwa Hong Kong adalah surganya para PMI perempuan, karena kehidupan sosial warga PMI di Hong Kong lebih terbuka, sehingga komunikasi diantara pekerja asal Indonesia sangat kental dan intensif, dimana setiap hari minggu ribuan pekerja wanita asal Indonesia memenuhi Victoria Park, mereka juga tampil tidak seperti domestic workers. Sebaliknya, PMI yang berada di Arab Saudi lebih tertutup karena mereka harus bekerja dalam sebuah lingkungan yang juga tertutup, tidak ada wadah untuk berkumpul dengan para PMI lainnya. Lihat https://setkab.go.id/hong-kong-surganya-tki/ di akse pada Rabu 6 Oktober 2021 pukul 19.00

${ }^{35}$ Laporan-laporan jurnalistik mengenai maraknya kajian-kajian keagamaan yang dilaksanakan oleh PMI di Hong Kong bertaburan di media massa online. Salah satunya bisa diliat di https://news.detik.com/berita/d-2185795/sisi-lain-tki-di-hong-kong-kelompok-pengajian--keterampilanmerajut atau melihat bagaimana mereka mengadakan kegiatan saat bulan ramadhan di https://www.bbc.com/indonesia/majalah-40317364
} 
Kong adalah para pekerja migran Indonesia ini, yang umumnya mengisi sektor lapangan kerja pembantu rumah tangga. Dan dengan mempertimbangkan profil komunitas muslim Indonesia di Hong Kong itu, yang umumnya adalah pekerja wanita, maka kebutuhan mendesak yang mereka hadapi adalah bimbingan dan pendidikan agama bagi diri mereka sendiri, berupa layanan pendidikan keagamaan non-formal. ${ }^{36}$

Seperti telah disebut sebelumnya, layanan pendidikan agama formal yang disediakan melalui sekolah-sekolah yang diorganisasi komunitas asli muslim di Hong Kong memang penting bagi generasi muslim yang lahir dan tumbuh di sana, namun tidak memiliki arti penting bagi komunitas muslim Indonesia yang berasal dari kalangan pekerja migran dalam sektor pembantu rumah tangga. Segmen ini datang ke Hong Kong hanya sebagai penduduk tidak tetap, yang juga tidak diperkenankan membawa anak dan keluarga, sehingga mereka tidak memiliki kebutuhan akan layanan pendidikan agama formal. Sebaliknya, Pendidikan keagamaan non-formal menjadi layanan yang sangat dibutuhkan bagi komunitas pekerja migran muslim Indonesia.

Lalu bagaimana pekerja migran muslim Indonesia memenuhi kebutuhan mereka akan layanan pendidikan keagamaan?. Pertama-tama mereka menghimpun diri dalam berbagai organisasi atau perkumpulan keagamaan, seperti majelis taklim di Indonesia. Mereka biasanya membentuk organisasi keagamaan sendiri, menentukan pengurus mereka sendiri, dan juga menyelenggarakan aktivitas pengajian sendiri. jadi benar-benar seperti organisasi dari mereka, oleh mereka, dan untuk mereka. Organisasi-organisasi ini memiliki fiungsi selain sebagai wqadah bagi mereka untuk menjalin komunikasi, ia juga dijadikan sebagai wadah aktivitas dan merencanakan kegiatan secara bersama-sama.

Dari beberapa hasil penelitian yang ada, jumlah organisasi keagamaan yang dibentuk pekerja migran Indonesia dapat mencapai ratusan. namun, baru sebanyak 55 organisasi yang bergabung dalam wadah Persatuan organisasi muslim Indonesia Hong Kong (POSMIH). ${ }^{37}$

36 Lihat, Alam, ............. Pendidikan, hal. 324
Dalam hal ini patut diingat bahwa organisasi yang didirikan oleh para PMI di Hong Kong bukan hanya
organisasi dengan basis kegiatan keagamaan belaka. Disana ada organisasi PMI yang berorientasi pada
pemberdayaan hukum dan hak mereka sebagai buruh di negeri orang, organisasi yang berorientasi pada
pemberdayaan jiwa wiraswasta buruh migran, dan lain sebagainya. Organisasi para pekerja migran ini
memiliki peran penting dalam melindungi, mengarahkan serta mendidik anggotanya. Sejalan dengan
konvensi International Labour Organization (ILO) tahun 1987, para buruh migran memunyai hak untuk
membentuk serikat- serikat dan asosiasi pekerja atas pilihan mereka sendiri. Mereka juga diperbolehkan
bergabung dan diwakili oleh serikat-serikat pekerja yang ada di negara-negara penerima. Organisasi Buruh
Migran Indonesia (BMI) di Hong Kong terbilang berkembang dan maju dibanding organisasi BMI yang 
Beberapa diantara organisasi-organisasi dengan basis kegiatan Pendidikan dan keagamaan patut dicatat berikut ini :

1. Majelis Ta'lim Taman Kerohanian Wanita Islam Indonesia-Hong Kong (MTTKWII HK) adalah organisasi Islam yang pertama kali di Hong Kong. MTTKWII didirikan pada tanggal 1 May 1994. Fokus kegiatan utamanya adalah Pendidikan dan kajian keagamaan yang dilakukan di Mushola Al Falah di dalam Gedung KJRI Hong Kong.

2. Forum Komunikasi Mu'minat Peduli Umat (FKMPU). Organisasi ini didirikan pada 1 Oktober 2000 dan mendapatkan lisensi dari KJRi Hong Kong pada 5 Oktober 2000. Kegiatan utamanya adalah Pendidikan keagamaan, pendidikan keterampilan, dan kewirausahaan.

3. Persatuan Dakwah Victoria (PDV). Sesuai dewngan Namanya, basis kegiatan organisasi ditempatkan di taman Victoria Park. Kegiatan utama organisasi ini beorientasi pada pendidikan keagamaan bagi buruh migrant di Hong Kong. Organisasi ini memiliki cakupan kegiatan yang luar biasa variative sehingga keragaman kegiatan keagamaan dan juga organisasi anggota dibawahnya menjadikan PDV salah satu organisasi muslim terbesar di Hong Kong.

4. Mar'atush Sholihah. Dididrikan pada 2007 Mar'atus Sholihah adalah sebuah organisasi BMI yang berasal dari Lampung. Kegiatan utama organisasi ini adalah pendidikan keagamaan dan pendidikan keterampilan.

5. Lentera Sosial Organisasi (LSO) Kegiatan utama organisASI INI ADALAH pendidikan DAN pengembangan kepribadian. Organisasi ini memiliki visi dan misi yang bergerak di dua bidang yaitu yaitu ; sosial dan pengembangan

\footnotetext{
ada di negara lainnya. Hal itu disebabkan Hong Kong merupakan negara yang menjunjung nilai-nilai persamaan hak, tidak membeda-bedakan manusia dan latar belakangnya. Begitu pula dengan kebebasan berorganisasi di Hong Kong dijamin sepenuhnya oleh pemerintah, sehingga BMI di Hong Kong memunyai kebebasan untuk berorganisasi dan berserikat sesuai dengan keinginan. Di Hong Kong ada banyak sekali organisasi dan asosiasi yang didirikan oleh PMI di antaranya adalah Indonesian Migrant Worker Union (IMWU), Asosiasi Tenaga Kerja Indonesia (ATKI), Koalisi Tenaga Kerja Indonesia Hong Kong (KOTHIKO), dan masih banyak lagi komunitas PMI lainnya. Kesempatan berorganisasi di Hong Kong tidak hanya berjejaring dengan organisasi asal Indonesia saja, akan tetapi dengan orgenisasi buruh migran dari negara lain, seperti Philipina, Srilanka, Thailand, dan India. Luar biasanya, pada waktu-waktu tertentu, organisasi PMI di Hong Kong juga selalu dilibatkan dalam rapat-rapat oleh pemerintahan Hong Kong dan juga perwakilan indonesia yang ada di Hong Kong kendatipun dalam beberapa mereka seringkali berseberangan. Lihat, https://buruhmigran.or.id/en/2012/01/13/selayang-pandang-organisasi-bmi-di-hongkong/ di akses pada 17 Oktober 2021 pukul 14.00
} 
diri. Taka da yang didapat mengenai kapan organisasiini diriikan. Selain Pendidikan keagamaan, LSO fokus pada diskusi kiat-kiat sosial berorganisasi. $^{38}$

Biasanya, organisasi-oraganisasi yang dibentuk secara mandiri oleh para pekerja miran tersebut melaksanakan kegiatan keagamaannya dibagi kedalam dua bentuk :

1. Aktivitas keagamaan reguler

2. Aktivitas keagamaan non-reguler.

Aktivitas Pendidikan keagamaan yang bersifat reguler adalah penyelengaraan Pendidikan keagamaan, berupa pengajian, setiap hari minggu, hari umumnya pekerja migran mengambil hak liburnya dalam seminggu. Aktivitas non-reguler berupa penyelenggaraan kegiatan pengajian, dengan mengundang berbagai tokoh agama atau penceramah, umumnya penceramah kondang yang berasal dari Indonesia.

Aktivitas pengajian reguler tersebut umumnya diadakan dengan memanfaatkan flat apartemen, masjid dan pusat keislaman yang ada, dan juga mushalla di KJRI Hong Kong. Tempat lain yang juga nyaman dan marak digunakan adalah lantai 3 di komplek masjid Ammar \& Osman Ramju Sadick Islamic Centre setiap Sabtu digunakan oleh pekerja migran untuk mengadakan aktivitas pengajian. Komplek itu sendiri buka setiap hari, dan untuk hari-hari selain Sabtu, tempat itu biasanya digunakan komunitas muslim dari berbagai bangsa, termasuk komunitas Indonesia nonpekerja pembantu rumah tangga.

Mengenai buku-buku pegangan yang dijadikan referensi dalam hal pengajaran tercatat beberapa judul buku berikut :

1. Untuk belajar membaca Al Quran, kitab pegangan yang biasa digunakan adalah Buku Iqra sebanyak 6 jilid yang disusun oleh As'ad Humam.

2. Untuk materi tafsir adalah Al Munir (fi al-'Aqidah wa al-Syari’ah wa alManhaj) karya Wahbah Al-Zuhayli dan Tafsir Al Azhar karya Prof Dr. Hamka.

3. Untuk materi fikih digunakan Fiqh Sunnah karya Sayyid Sabiq

4. Untuk materi Tauhid/Aqidah digunakan kurikulum dari malaysia. ${ }^{39}$

38 Lihat, Siti Nurlaili Muhadiyatiningsih, Islam di Hong Kong (Kajian Kebudayaan), dalam Eprint Repository, IAIN Surakarta 2021, hal.

39 Alam, .... Pendidikan Keagamaan, hal. 337 
Mushalla Al Falah, yang terdapat di KJRI Hong Kong juga kerap digunakan untuk aktivitas pengajian pekerja migran ketika mereka libur, terutama hari Sabtu dan minggu. Selain itu, pekerja migran juga menggunakan fasilitas publik, berupa taman, untuk aktivitas mereka.

Fasilitas publik di Hong Kong yang favorit digunakan pekerja migran Indonesia untuk menyelenggarakan aktivitas pendidikan keagamaan non-formal, dan sebenarnya juga aktivitas non keagamaan lainnya, adalah taman victoria (Victoria Park), yang terletak di daerah Causeway bay, Distrik Eastern, hong Kong Island.

Terutama pada hari minggu taman itu dihadiri oleh ribuan pengunjung dengan beragam kepentingan yang berbeda. Ada yang sekadar bersantai untuk melepas diri sejenak dari rutinitas kehidupan di hong Kong. Ada yang berolahraga. Ada yang menggelar acara dengan mengundang pembicara terkait motivasi. Ada pula komunitas yang memanfaatkan taman ini untuk menggelar aktivitas Pendidikan keagamaan.

Salah satu aktivitas Pendidikan keagamaan yang sempat peneliti observasi adalah pendidikan baca Al Quran yang difasilitasi oleh tutor dari Lembaga Pengembangan tilawatil Quran (LPTQ) Dompet Dhuafa. berdasarkan pengamatan, ada sekitar 3 kelompok, dengan masingmasing kelompok terdiri atas 10-12 peserta, yang sedang melakukan aktivitas membaca Al Quran di bawah tenda putih yang tersedia di taman.

Selain aktivitas pengajian reguler, seperti telah disebut, organisasi-organisasi keislaman Indonesia juga mengadakan aktivitas pengajian non reguler, biasanya berupa acara pengajian dengan mendatangkan narasumber atau penceramah dari Indonesia. Beberapa penceramah kondang yang pernah diundang komunitas muslim Indonesia di hong Kong adalah Ustadz Arifin Ilham, Yusuf Mansur, Maulana, dan Sholeh Mahmoed Nasution, yang dikenal dengan panggilan "Solmed". Aktivitas itu umumnya dilakukan dengan menyewa tempat di aula, atau tempat tertutup di taman, dan mengenakan tiket bayaran untuk peserta yang menghadiri kegiatan tersebut. ${ }^{40}$

Aktivitas mendatangkan penceramah dari Indonesia, dengan segala biaya yang harus ditanggung oleh pekerja migran tersebut tidak lain mencerminkan kebutuhan luar biasa para pekerja migran Indonesia akan siraman rohani atau nasihat keagamaan dari tokoh-tokoh agama. Kebutuhan pekerja migran yang tinggi akan kehadiran pembimbing

40 Ibid, ....... hal. 335 
agama, sementara sementara disisi lain mereka juga berhadapan dengan kesulitan jarak, waktu, tenaga dan biaya yang mereka miliki, menyebabkan terbukanya celah yang dimanfaatkan oleh oknum-oknum tertentu untuk mencari keuntungan atas nama aktivitas dakwah atau keagamaan lainnya.

Sangat tingginya kebutuhan akan layanan bimbingan dan pendidikan keagamaan pekerja migran Indonesia di hong Kong disinyalir oleh Rudi harisyah alam sebagai, "telah membuka peluang bagi oknum-oknum tertentu yang hendak meraup keuntungan, atau bahkan melakukan aksi penipuan, atas nama dakwah dan pembinaan keagamaan bagi komunitas pekerja migran Indonesia di Hong Kong". ${ }^{41}$

Dalam konteks ini, kita sudah seharusnya memberikan perhatian lebih terhadap gairah mereka untuk menimba ilmu agama. Dikahawatirkan mereka akan terjerembab pada ajaran-ajaran keagamaan radikal dan ekstrem yang tidak selaras dengan tradisi keberagamaan bangsa Indonesia. Gairah mereka untuk mendapatkan pendidikan agama serta kajian intensif mereka yang dilaksanakan secara rutin dan tersebar pada berbagai kelompok pengajian di Hong kong sangat membuka kemungkinan hadirnya pihak-pihak yang ingin memanfaatkan mereka untuk menyusupkan pemikiran-pemikiran keagamaan radikal yang berbahaya.

\section{PENUTUP}

Bekerja dan mencari nafkah di negeri yang masyarakatnya memiliki kebudayaan dan kepercayaan berbeda, sebagaimana dialami oleh para pekerja migran Indonesia (PMI) di Hong Kong, memberikan kepada kepada kita sudut pandang tersednri dalam menghayati karakteristik keberagamaan sebagian saudara kita yang tengah berada di manca negara.

Berada dalam hubungan kerja dengan pengguna jasa antara buruh dan majikan, PMI harus menghadapi ragam perbedaan budaya, ekspresi, nalar, dan tidak jarang kepercayaan. Gegar budaya ini dapat diperburuk dengan adanya keterpisahan dengan figur-figur lekat: keluarga. Gegar budaya, adaptasi dan keterpisahan berpotensi menjadi persoalan sekaligus bisa menjadi kekuatan bagi PMI. Berangkat dari pengalaman tersebut dan persentuhan bersama PMI lain selama bertahun-tahun, terutama di Hong Kong, agama kerap menjadi satu perhatian khusus PMI. Hidup di negara dengan mayoritas

41 Ibid ......., hal. 337 
penduduk beragama berbeda merupakan sebuah tantangan bagi setiap PMI. Kebutuhan untuk menjalankan agama dan penyesuaian diri dengan kondisi ruang bekerja seringkali membingungkan PMI dan memunculkan pertentangan batin.

Itu sebabnya mengapa, seperti yang kita baca dalam keterangan panjang diatas, para pekerja migran tersebut berusaha semaksimal mungkin menggiunakan fasilitas yang sangat minim mereka tersedia bagi mereka untuk mendapatkan siraman batin berupa Pendidikan agama. Waktu libur yang hanya sehari dalam seminggu, sewrta ruang-ruang public tidak secara khusus tersedia bagi mereka adalah lahan yang terus menerus mereka gali dan sirami dengan berbagai kegiatan untuk mendapatkan petuah-petuah keagamaan yang menyejukkan. Justru demi menjaga keseimbangan jiwa mereka di tengah budaya yang luar biasa berbeda yang mereka hadapi saban hari.

Betapa luar biasa, di tengah kesibukan bekerja dalam situasi di mana infrastruktur untuk menjalankan kewajiban keagamaan serba terbatas, bahkan mungkin tidak mendukung sama sekali, para buruh migran masih tetap saja memikirkan cara yang legal dan sah dalam menjalani rute keberagamaan. Situasi seperti akan tampak biasa saja di Indonesia karena kondisi yang mereka hadapi memang tidak ditemukan di Indonesia, mengingat

perbedaan demografi, geografi, dan budaya. Islam yang mayoritas dan dominan di Indonesia tidak ditemukan di Hong Kong.

Dalam hal ini, sudah seharusnyalah pemerintah Republik memberikan kepedulian yang lebih terhadap kebuuhan akan Pendidikan agama ini. Perhatian ini bisa saja diwujudkan dalam bentuk sokongan kepada setiap organisasi yang didirikan oleh para pekerja migran di Hong Kong dalam bentuk baik moril maupun materiil. Memberikan kajian rutin yang difasilitasi oleh pemerintah RI melalui KJRI di Hong Kong, menyediakan tempat yang lebih layak untuk mereka belajar daripada sekedar mushalla di Gedung KJRI, mendatangkan da'i atau ustadz yang ideologi keagamaannya selaras dengan nilai-nilai keislaman Indonesia, sampai pada mendirikan lembaga pendidikan keagamaan khusus untuk pekerja migran Indonesia sepertinya sangat dibutuhkan guna memperteguh komitmen pemerintah untuk melindungi dan sekaligus menyejahterakan rakyatnya baik lahir maupun bati, baik di dalam negeri maupun di luar negeri. 
Akhirul kalam, tulisan diatas memberikan gambaran kepada kita bahwa ditengah hiruk pikuknya gaya hidup materialistis sebagian bangsa kita yang justru berada didalam negeri sendiri, kita patut menengok pada semangat profetis dan religious saudara-saudara kita yang berada jauh disana di manca negara. Ditengah kesibukan mereka bekerja mencari nafkah dan berjuang antara hidup dan mati di negeri orang, mereka masih bertanya dan terus mencari nilai-nilai moral religius untuk terus mereka dekapi dan mereka praktekkan dalam hidup keseharian mereka. Mereka tak larut dalam arus hidup kebendaaan yang mampu membuat jiwa mereka kehilangan kesucian dan keseimbangan.

"Sesungguhnya beruntunglah orang yang membersihkan diri (dengan beriman) dan ia ingat nama Tuhannya, lalu ia sembahyang. Tetapi kamu (orang-orang kafir) memilih kehidupan duniawi. Sedang kehidupan akhirat adalah lebih baik dan lebih kekal." $" 42$

\section{Daftar Pustaka}

Alam, Rudi Harisyah (2016), Pendidikan Keagaman pada Komunitas Muslim Indonesia di Hong Kong, dalam Jurnal Edukasi, Jurnal Penelitian Pendidikan agama dan Keagamaan, Vol 14 No, 3 (Desember 2016).

Anshor, Syaiful, 2013, Sisi Gelap dan Terang Buruh Migran di Hong Kong, dalam Suara Hidayatulloh, edisi Juli 2013, Jakarta.

Baihaqi, Agus, et al, Komunikasi Keluarga Buruh Migran Indonesia: Masalah dan Penyelesaian, dalam Jurnal JIKE Vol. 1, No. 2 (Juni, 2018)

Bakhtiar, Amsal, (2007), Filsafat Agama, Wisata Pemikiran dan Kepercayaan Manusia, (Jakarta, Raja Grafindo Persada)

Dadan Muhanda, Asep, (2012), Idul Fitri di Hong Kong, dalam Harian Bisnis Indonesia, edisi 27 desember 2012.

Darthayasa, I Nengah, et al, (2016), Pengalaman Tenaga Kerja Indonesia (TKI) yang Mengalami Abuse, Jurnal Ilmu Keperawatan Vol. 4 No. 2 (November, 2016)

E. Mulyasa, E, (2005), Menjadi Guru Profesional Menciptakan Pembelajaran Kreatif dan Menyenangkan, (Bandung: Remaja Rosda Karya, 2005)

Gerber, Chatheriene, (2010), Eyewitness Travel Top 10 Hong Kong, Penerbit Erlangga, Jakarta

42 Al Quran surat Al A'la (87) 14-17 
Latif, Yudi. (2014). Mata Air Keteladanan: Pancasila dalam Perbuatan. (Bandung, Mizan)

Lelisari, Imawanto, Hamdi, Sosialisasi Undang-Undang No 18 Tahun 2017 Tentang Pelindungan Pekerja Migran Indonesia Di Desa Bonjeruk Kecamatan Jonggat Kabupaten Lombok Tengah, dalam Selaparang, Jurnal pengabdian Masyarakat Berkemajuan, Vol. 4 No. 2 (April 2021).

Moreno, Francisco J, (2000) Agama Dan akal Pikiran, Naluri Rasa Takut dan Keadaan Jiwa Manusia, (Jakarta, Rajawali Press)

Mulyana. A. (2013). Potret Karakter Manusia Indonesia Dalam Dinamika Identitas Kebangsaan. Jurnal Pendidikan Sosial \& Ekonomi, Vol. 2 No. 2

Muslich, \& Qohar, A. (2014). Nilai-nilai Universal Agama-Agama di Indonesia : Menuju Indonesia Maju, (Yogyakarta: Kaubaka)

Naim, Mochtar, (2013), Merantau, Pola Migrasi Suku Miangkabau, (Jakarta, Rajawali Press)

Romdiati, Haning, (2012)"Migrasi Tenaga Kerja Indonesia dari Tulungagung: Kecenderungan dan Arah Migrasi serta Remitansi”, Jurnal Kependudukan Indonesia Vol. VI, No. 2 (Desember, 2012)

Muhadiyatiningsih, Siti Nurlaili, (2021), Islam di Hong Kong (Kajian Kebudayaan), dalam Eprint Repository, IAIN Surakarta 2021

Smith, Huston, (2015), Agama-Agama Manusia, (Jakarta, Serambi)

Sudijono, Anas, (2009), Pengantar Evaluasi Pendidikan, (Jakarta, Raja Grafindo Persada)

Wahid, Marzuki, \& Imam Nakha'i, (2021) Fiqih Pekerja Migran: Mengenal Fiqih dan Problematika Keagaamaan Pekerja Migran Indonesia”. (Infest, Yogjakarta)

Siregar, Wahidah Zein Br, (2020), Kisah Perempuan Pekerja Migran Indonesia Di Hong Kong: Perjuangan Untuk Keluarga Dan Pendidikan Anak, dalam Al Hukama, The Indonesian Journal of Islamic Family Law, Volume 10, Nomor 02, Desember 2020

Zulkarnain, (2017), Warga Negara Religius sebagai Identitas Kewarganegaraan di Indonesia, Prosiding Konferensi Nasional Kewarganegaraan III, Universitas Ahmad Dahlan, Yogyakarta, 11 November 2017.

\section{Referensi dari internet}

https://buruhmigran.or.id/en/2019/03/22/beragama-di-negeri-minoritas-muslim/ 
https://news.detik.com/berita-jawa-timur/d-4387663/tkw-asal-malang-meninggal-diHongKong-dikabarkan-bunuhdiri?_ga=2.189246955.1540539177.1641705687-978666873.1641705687

http://www. grid.id

http://migranpos.com/2019/09/27/kuliah-sambil-bekerja-150-pmi-wisuda-di-kapalpesiar/

https://bp2mi.go.id/profil-sejarah diakses pada 1 Oktober 2021 pukul 09.00

https://id.wikipedia.org/wiki/Daftar_negara_menurut_jumlah_penduduk

https://menara62.com/kebutuhan-tenaga-kerja-migran-kota-hong-kong-meningkat/

https://buruhmigran.or.id/2011/05/15/informasi-negara-tujuan-tki-Hong Kong/

https://ekonomi.kompas.com/read/2019/01/22/063800826/pekerja-indonesia-di-hongkong-terus-bertambah-berapa-gajinya

https://indonesiaglobalworker.com/2019/07/20/hong-kong-referensi-impian-parapekerja-migran-indonesia/

https://setkab.go.id/hong-kong-surganya-tki/ yang merupakan situs resmi Sekretariat Kebinet Republik Indonesia

https://setkab.go.id/hong-kong-surganya-tki/

https://news.detik.com/berita/d-2185795/sisi-lain-tki-di-hong-kong-kelompok-

pengajian--keterampilan-merajut

https://www.bbc.com/indonesia/majalah-40317364

https://buruhmigran.or.id/en/2012/01/13/selayang-pandang-organisasi-bmi-di-hongkong/ 